\title{
Case report: contradictory genetics and imaging in focal congenital hyperinsulinism reinforces the need for pancreatic biopsy
}

Daphne Yau ${ }^{1,2^{*}+}$ (D) Ria Marwaha ${ }^{1 \dagger}$, Klaus Mohnike ${ }^{3}$, Rakesh Sajjan ${ }^{4}$, Susann Empting ${ }^{3}$, Ross J. Craigie ${ }^{5}$, Mark J. Dunne ${ }^{6}$, Maria Salomon-Estebanez ${ }^{1}$ and Indraneel Banerjee ${ }^{1}$

\begin{abstract}
Background: Congenital Hyperinsulinism (CHI) is an important cause of severe hypoglycaemia in infancy due to excessive, dysregulated insulin secretion. In focal $\mathrm{CHI}$, a localised lesion within the pancreas hypersecretes insulin and, importantly, hypoglycaemia resolution is possible through limited surgical resection of the lesion. Diagnosis of focal $\mathrm{CH}$ is based on a crucial combination of compatible genetics and specialised imaging. Specifically, a focal lesion arises due to a paternal mutation in one of the ATP-sensitive potassium channel genes, KCNJ11 or ABCC8, in combination with post-zygotic loss of maternal heterozygosity within the affected pancreatic tissue. 6-[18F]Fluoro-L3,4-dihydroxyphenylalanine $\left({ }^{18} \mathrm{~F}-\mathrm{DOPA}\right)$ positron emission tomography (PET)/computed tomography (CT) imaging is used to detect and localise the lesion prior to surgery. However, its accuracy is imperfect and needs recognition in individual case management.

Case presentation: We report the case of an infant with hypoglycaemia due to $\mathrm{CHI}$ and a paternally inherited KCNJ11 mutation, c.286G > A (p.Ala96Thr), leading to a high probability of focal CHI. However, ${ }^{18} \mathrm{~F}-\mathrm{DOPA}$ PET/CT scanning demonstrated diffuse uptake and failed to conclusively identify a focal lesion. Due to unresponsiveness to medical therapy and ongoing significant hypoglycaemia, surgery was undertaken and a small $4.9 \times 1.7 \mathrm{~mm}$ focal lesion was discovered at the pancreatic neck. This is the second case where this particular KCNJ11 mutation has been incorrectly associated with diffuse ${ }^{18} \mathrm{~F}$-DOPA uptake, in contrast to the correct diagnosis of focal $\mathrm{CHI}$ confirmed by pancreatic biopsy.
\end{abstract}

Conclusions: Identifying discrepancies between genetic and imaging investigations is crucial as this may negatively impact upon the diagnosis and surgical treatment of focal $\mathrm{CHI}$. This case highlights the need for pancreatic biopsy when a strong suspicion of focal $\mathrm{CH}$ is present even if ${ }^{18} \mathrm{~F}$-DOPA imaging fails to demonstrate a discrete lesion.

Keywords: Focal congenital hyperinsulinism, Fluorodopa F 18, Positron emission tomography computed tomography, KATP channels, Kir6.2 channel

\footnotetext{
* Correspondence: daphne.yau@usask.ca

${ }^{\dagger}$ Daphne Yau and Ria Marwaha are joint first authors.

'Department of Paediatric Endocrinology, Royal Manchester Children's

Hospital, Manchester M13 9WL, UK

2Department of Pediatrics, University of Saskatchewan, Royal University Hospital, 103 Hospital Drive, Saskatoon, Saskatchewan S7N 0W8, Canada

Full list of author information is available at the end of the article
}

C C The Author(s). 2020 Open Access This article is licensed under a Creative Commons Attribution 4.0 International License, which permits use, sharing, adaptation, distribution and reproduction in any medium or format, as long as you give appropriate credit to the original author(s) and the source, provide a link to the Creative Commons licence, and indicate if changes were made. The images or other third party material in this article are included in the article's Creative Commons licence, unless indicated otherwise in a credit line to the material. If material is not included in the article's Creative Commons licence and your intended use is not permitted by statutory regulation or exceeds the permitted use, you will need to obtain permission directly from the copyright holder. To view a copy of this licence, visit http://creativecommons.org/licenses/by/4.0/ The Creative Commons Public Domain Dedication waiver (http://creativecommons.org/publicdomain/zero/1.0/) applies to the data made available in this article, unless otherwise stated in a credit line to the data. 


\section{Background}

Congenital Hyperinsulinism (CHI) is an important cause of severe hypoglycaemia in infancy due to excessive, dysregulated insulin secretion [1]. In CHI, the most common genetic aetiology is a mutation in one of the potassium ATP $\left(\mathrm{K}_{\mathrm{ATP}}\right)$ channel genes, $A B C C 8$ or KCNJ11. This channel links glucose metabolism to insulin release in the pancreatic betacell. Recessive $\mathrm{K}_{\mathrm{ATP}}$ mutations in the homozygous or compound heterozygous state cause diffuse $\mathrm{CHI}$, in which beta-cells throughout the entire pancreas are abnormal and hypersecrete insulin [2]. Diffuse CHI due to $K_{\text {ATP }}$ mutations is typically unresponsive to medication, requiring subtotal pancreatectomy to achieve normoglycaemia.

In focal $\mathrm{CHI}$, another form of $\mathrm{CHI}$ that is also generally medication-unresponsive, only a small region of the pancreas is affected by pathology [1]. The focal lesion occurs due to a paternally inherited mutation in $A B C C 8$ or KCNJ11 combined with postzygotic loss of maternal heterozygosity within the affected tissue. The latter causes clonal expansion of endocrine rich tissue due to the loss of cell cycle repressor genes that are expressed from the maternal allele [2]. Excess insulin results from the clonally expanded, abnormal beta-cells expressing the mutated ATP-sensitive potassium channel. Focal $\mathrm{CHI}$ can be cured by limited resection, compared with more extensive pancreatectomy, which is associated with significant risk of lifelong diabetes and exocrine insufficiency.

Distinguishing focal CHI from other forms is therefore critical, and its diagnosis is based on a crucial combination of compatible genetics (i.e. paternal mutation in KCNJ11 or $A B C C 8)$ and 6-(18F)FluoroL-3,4-dihydroxyphenylalanine $\left({ }^{18} \mathrm{~F}\right.$-DOPA) positron emission tomography (PET)/CT imaging which localises the lesion $[1,2]$. Uptake of ${ }^{18} \mathrm{~F}$-DOPA by pancreatic beta-cells occurs due to expression of aromatic amine decarboxylase (AADC), resulting in conversion of L-DOPA to dopamine and sequestration of the radiotracer within the beta-cells [3, 4]. Focal lesions are distinguishable from the remainder of the pancreas due to uptake and sustained retention of the radiotracer by the hyperplastic, clonallyexpanded beta-cells within the lesion, in contrast to the rest of the pancreas [4]. The mechanism for this remains unclear.

${ }^{18} \mathrm{~F}$-DOPA PET/CT represents a significant advance over the invasive and technically challenging technique of pancreatic arterial calcium stimulation with hepatic venous sampling previously used to identify focal lesions [4]. However, while this modality remains the investigation of choice to non-invasively identify a focal CHI lesion prior to surgery, with greater experience, it has been found to be less sensitive in detecting focal lesions than originally reported $[5,6]$. We report a case in which a paternally inherited KCNJ11 mutation was associated with diffuse ${ }^{18} \mathrm{~F}$-DOPA uptake but later confirmed to have focal $\mathrm{CHI}$ at the time of surgery.

\section{Case presentation}

A male infant was born at 39 weeks' gestation with a birth weight of $4.34 \mathrm{~kg}$ (98-99.6th percentile) after an uncomplicated pregnancy and normal delivery. Profound hypoglycaemia was noted with poor feeding and irritability in the early neonatal period. $\mathrm{He}$ required an elevated glucose infusion rate of $15.4 \mathrm{mg} / \mathrm{kg} / \mathrm{min}$ to achieve normoglycaemia. Consistent with this, CHI was confirmed with raised insulin and c-peptide at the time of hypoglycaemia (glucose $1.8 \mathrm{mmol} / \mathrm{L}$, insulin $140 \mathrm{pmol} / \mathrm{L}$, c-peptide $741 \mathrm{pmol} / \mathrm{L}$ ). There were no dysmorphic features or other medical problems to suggest a syndromic aetiology. He was unresponsive to medical therapy with persistent need for high dextrose infusion despite maximum doses of diazoxide and octreotide, the mainstays of medical treatment, which act by inhibiting insulin release.

Genetic testing revealed a paternally inherited mutation in KCNJ11, c.286G > A (p.Ala96Thr), suggesting the presence of focal CHI. This mutation has previously been described as recessive and a cause for focal $\mathrm{CHI}$ in another patient [7]. However, ${ }^{18} \mathrm{~F}$-DOPA PET/CT scanning demonstrated diffuse uptake throughout the entire pancreas (Fig. 1A-C). Both ordered subset expectation maximization (OSEM) and ultra-high definition (UHD) reconstruction were performed on the PET images and standardised uptake values (SUV) measurements were obtained at each time point (5-15 $\mathrm{min}, 15-30 \mathrm{~min}, 30-45 \mathrm{~min}, 45-60$ min and $60-80 \mathrm{~min}$ ) at the following sites: pancreatic head, body, tail, and region of most avid uptake (Table 1). In addition, maximum intensity projection (MIP) images were visually inspected for localised increased radiotracer concentrations, but there was no obvious localisation of a focal lesion.

The uptake was quantified by calculating SUV ratios for the area of most avid intake, which was in the proximal body, at 45-60 min (Table 1). The maximum SUV value was normalized to the mean of the entire pancreas for both OESM and UHD reconstruction, giving ratios of $6.9 / 6.1=1.1$ and $10.7 / 8.7=1.2$ respectively, whereas a ratio of $>1.5$ is generally considered predictive of focal disease.

The authors of the previous patient with the same KCNJ11 mutation and focal CHI were contacted to share 


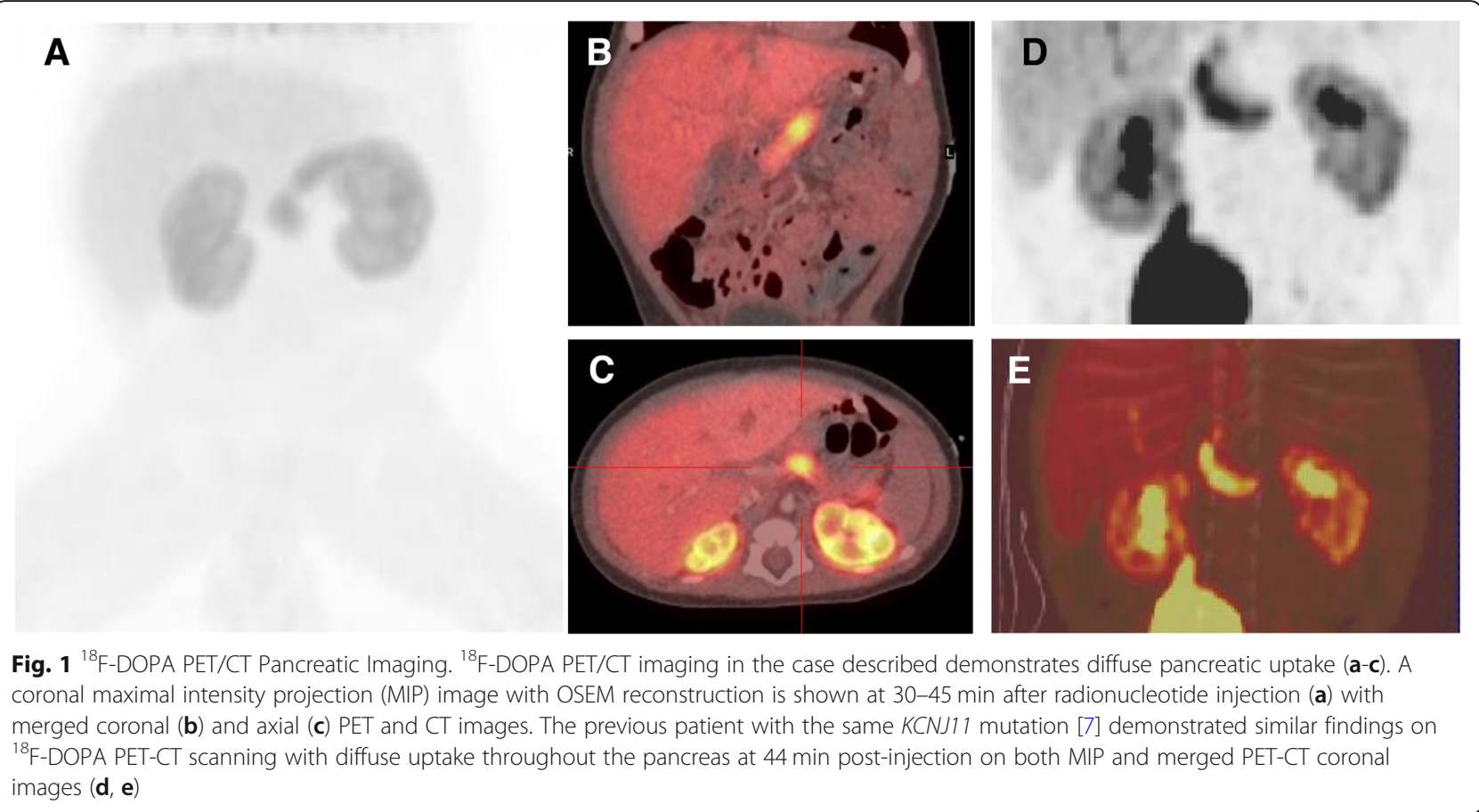

their experience to guide clinical management [7]. Similar scan findings to our case were noted (Fig. 1D-E). As this previous child's condition had been unstable with no response to medical therapy, surgery had been performed and a focal lesion was identified. Hypoglycaemia resolved after surgery.

Given this outcome, the decision was made to proceed to pancreatic biopsy, leading to the identification of a $4.9 \mathrm{~mm}$ by $1.7 \mathrm{~mm}$ lesion at the pancreatic neck. The histology demonstrated islands of endocrine cells, predominantly insulin and proinsulin positive, interspersed by bands of fibrous tissue and some acinar cells, consistent with a focal lesion (Fig. 2). Additional biopsy of the pancreatic tail showed normal pancreatic tissue without evidence of hyperplasia. After resection of the focal lesion, hypoglycaemia resolved and the patient was able to maintain an age-appropriate duration of fasting on regular feeds.

\section{Discussion and conclusions}

We describe the case of patient with focal $\mathrm{CHI}$ and discordant genetic and imaging findings. Although the patient possessed a paternally inherited $\mathrm{K}_{\mathrm{ATP}}$ mutation, diffuse uptake was seen on ${ }^{18} \mathrm{~F}$-DOPA PET/CT scan and ultimately, pancreatic biopsy was required to identify and confirm the focal lesion.

While the inheritance of a recessive paternal $\mathrm{K}_{\mathrm{ATP}}$ mutation is a key feature in the diagnosis of focal $\mathrm{CHI}$, the

Table 1 SUV from both OSEM and UHD reconstruction of the ${ }^{18} \mathrm{~F}$-DOPA PET Imaging shown up to a post injection duration of $60 \mathrm{~min}$

\begin{tabular}{|c|c|c|c|c|c|}
\hline & \multirow{2}{*}{$\begin{array}{l}\text { Reconstruction } \\
\text { Format }\end{array}$} & \multicolumn{4}{|c|}{ Time Post ${ }^{18} \mathrm{~F}$-DOPA Administration (mins) } \\
\hline & & $5-15$ & $15-30$ & $30-45$ & $45-60$ \\
\hline \multirow[t]{2}{*}{ Region of most avid uptake } & OESM & 6.0 & 6.8 & 6.7 & 6.9 \\
\hline & UHD & 9.2 & 10.9 & 10.4 & 10.7 \\
\hline \multirow[t]{2}{*}{ Head } & OESM & 6.7 & 6.5 & 6.5 & 6.5 \\
\hline & UHD & 9.2 & 9.8 & 9.3 & 9.2 \\
\hline \multirow[t]{2}{*}{ Body } & OESM & 6.7 & 6.6 & 6.6 & 6.0 \\
\hline & UHD & 9.8 & 9.4 & 8.7 & 8.5 \\
\hline \multirow[t]{2}{*}{ Tail } & OESM & 5.7 & 5.8 & 6.1 & 5.9 \\
\hline & UHD & 8.4 & 9.0 & 9.6 & 8.5 \\
\hline \multirow[t]{2}{*}{ Mean } & OESM & 6.3 & 6.3 & 6.4 & 6.1 \\
\hline & UHD & 9.1 & 9.4 & 9.2 & 8.7 \\
\hline
\end{tabular}




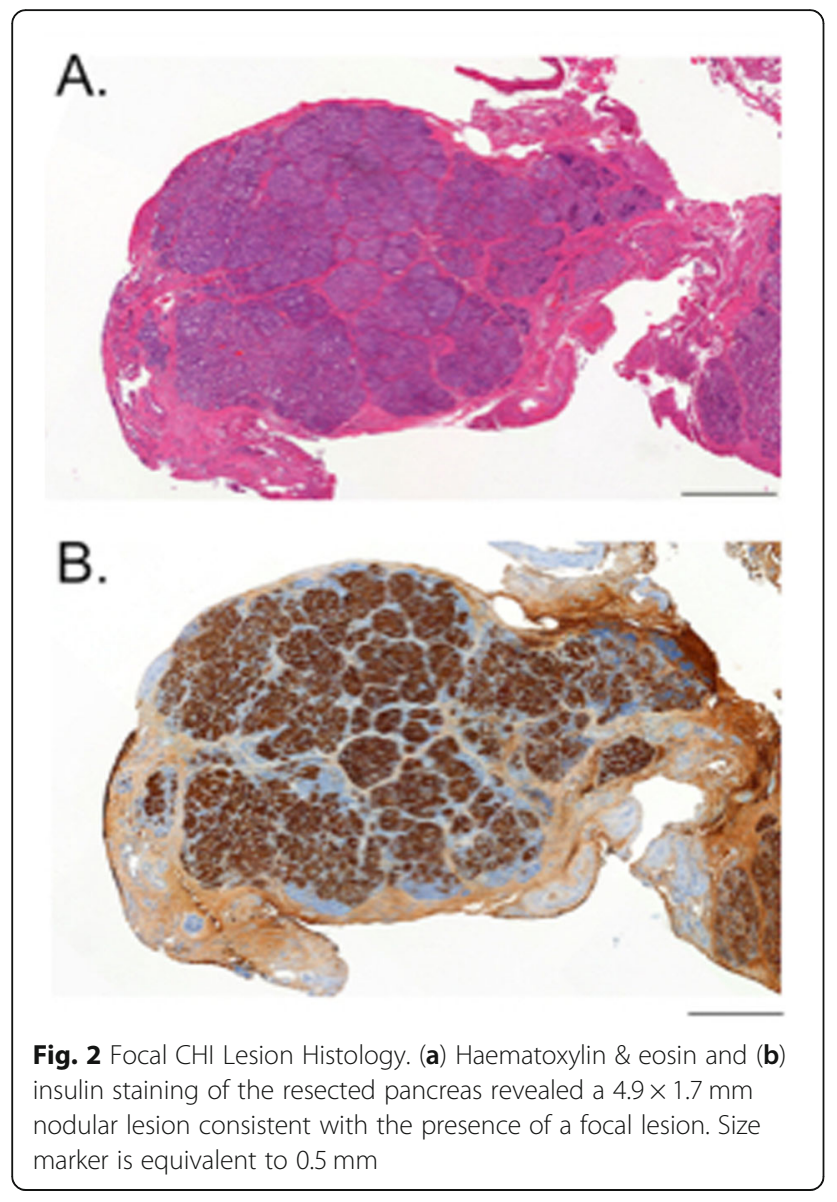

presence of pancreatic loss of heterozygosity and histologic confirmation of a focal lesion cannot be determined without biopsy of the tissue. While ${ }^{18} \mathrm{~F}$-DOPA $\mathrm{PET} / \mathrm{CT}$ is used to identify and localise focal $\mathrm{CHI}$ lesions prior to surgery $[1,2]$, it is important to recognise the possibility of discordant outcomes, as demonstrated by this case.

The reason for under-detection of focal lesions is unclear. Given the postulated mechanism of AADC beta-cell expression, and sequestration of L-DOPA following conversion to dopamine, localised tracer uptake by the clonally-expanded beta-cells would be expected to occur for all focal lesions. One potential mechanism may be related to lesion size [6]. False negative results have been attributed to both large and small focal lesions, with the smallest reported lesion detected by ${ }^{18} \mathrm{~F}$-DOPA PET/CT being $5 \times 4 \mathrm{~mm}$ $[6,8]$. It is possible that the lesion in our patient was too small at $4.9 . \times 1.7 \mathrm{~mm}$ for detection. Of note, this lesion is one of the smallest lesions identified at our centre.

Similar discordance in imaging findings have been observed in a separate case with the same mutation [7]. This raises the possibility of a mutation specific imaging outcome, although without a mechanistic explanation. Alternatively, the findings could be purely coincidental. Regardless, this case highlights the need for intra-operative pancreatic biopsy if focal $\mathrm{CHI}$ is strongly suspected but ${ }^{18} \mathrm{~F}$-DOPA PET/CT scanning fails to identify a well delineated focal lesion. Our case reinforces the importance of pancreatic biopsy in order to avoid unnecessary extensive pancreatectomy in focal $\mathrm{CHI}$ and the attendant future risks of diabetes and exocrine insufficiency.

\section{Abbreviations}

AADC: aromatic amine decarboxylase; $\mathrm{CHI}$ : congenital hyperinsulinism; CT: computed tomography; ${ }^{18} \mathrm{~F}$-DOPA: 6-(18F)Fluoro-L-3,4dihydroxyphenylalanine; PET: positron emission tomography

\section{Acknowledgements}

Not applicable.

\section{Authors' contributions}

DY collected the patient data, wrote and revised the manuscript. RM collected the patient data and drafted the manuscript. KM and SE provided data on the previous published case, including imaging data. RS analysed and provided the patient imaging data. RJC provided the pancreatic tissue sample. MJD performed the histological analysis. IB conceived of the case report, while IB and MSE were major contributors in editing the manuscript. All authors read and approved the final manuscript.

\section{Funding}

Funding was provided by the Northern Congenital Hyperinsulinism (NORCHI) charitable fund.

\section{Availability of data and materials}

Data sharing is not applicable to this article as no datasets were generated or analysed during the current study.

\section{Ethics approval and consent to participate}

Not applicable.

\section{Consent for publication}

Written informed consent for publication was obtained from the families of both patients.

\section{Competing interests}

The authors declare that they have no competing interests.

\section{Author details}

${ }^{1}$ Department of Paediatric Endocrinology, Royal Manchester Children's Hospital, Manchester M13 9WL, UK. ²Department of Pediatrics, University of Saskatchewan, Royal University Hospital, 103 Hospital Drive, Saskatoon, Saskatchewan S7N 0W8, Canada. ${ }^{3}$ Department of Paediatrics, Otto von Guericke University Magdeburg, 39106 Magdeburg, Germany. ${ }^{4}$ Nuclear Medicine Centre, New Saint Mary's Hospital, Manchester University Foundation Trust, Manchester M13 9WL, UK. ${ }^{5}$ Department of Paediatric Surgery, Royal Manchester Children's Hospital, Manchester M13 9WL, UK. ${ }^{6}$ Faculty of Biology, Medicine and Health, University of Manchester, Manchester M13 9PL, UK.

Received: 22 May 2020 Accepted: 31 July 2020

Published online: 31 August 2020

\section{References}

1. Banerjee I, Avatapalle B, Padidela R, Stevens A, Cosgrove KE, Clayton PE, et al. Integrating genetic and imaging investigations into the clinical management of congenital hyperinsulinism. Clin Endocrinol. 2013;78(6):803-13.

2. Stanley CA. Perspective on the genetics and diagnosis of congenital Hyperinsulinism disorders. J Clin Endocrinol Metab. 2016;101(3):815-26. 
3. de Lonlay P, Simon-Carre A, Ribeiro MJ, Boddaert N, Giurgea I, Laborde K, et al. Congenital hyperinsulinism: pancreatic [18F]fluoro-Ldihydroxyphenylalanine (DOPA) positron emission tomography and immunohistochemistry study of DOPA decarboxylase and insulin secretion. J Clin Endocrinol Metab. 2006;91(3):933-40.

4. Gopal-Kothandapani JS, Hussain K. Congenital hyperinsulinism: role of fluorine-18L-3, 4 hydroxyphenylalanine positron emission tomography scanning. World J Radiol. 2014;6(6):252-60.

5. Blomberg BA, Moghbel MC, Saboury B, Stanley CA, Alavi A. The value of radiologic interventions and (18)F-DOPA PET in diagnosing and localizing focal congenital hyperinsulinism: systematic review and meta-analysis. Mol Imaging Biol. 2013;15(1):97-105.

6. Santhanam P, Taïeb D. Role of (18) F-FDOPA PET/CT imaging in endocrinology. Clin Endocrinol. 2014;81(6):789-98.

7. Mohnike K, Wieland I, Barthlen W, Vogelgesang S, Empting S, Mohnike W, et al. Clinical and genetic evaluation of patients with KATP Channel mutations from the German registry for congenital Hyperinsulinism. Horm Res Paediatr. 2014;81:156-68.

8. Kühnen P, Matthae R, Arya V, Hauptmann K, Rothe K, Wächter S, et al. Occurrence of giant focal forms of congenital hyperinsulinism with incorrect visualization by (18) F DOPA-PET/CT scanning. Clin Endocrinol. 2014:81(6):847-54.

\section{Publisher's Note}

Springer Nature remains neutral with regard to jurisdictional claims in published maps and institutional affiliations.

Ready to submit your research? Choose BMC and benefit from:

- fast, convenient online submission

- thorough peer review by experienced researchers in your field

- rapid publication on acceptance

- support for research data, including large and complex data types

- gold Open Access which fosters wider collaboration and increased citations

- maximum visibility for your research: over $100 \mathrm{M}$ website views per year

At $\mathrm{BMC}$, research is always in progress.

Learn more biomedcentral.com/submissions 